\title{
Thauera selenatis gen. nov., sp. nov., a Member of the Beta Subclass of Proteobacteria with a Novel Type of Anaerobic Respiration
}

\author{
J. M. MACY, ${ }^{1 *}$ S. RECH, ${ }^{1} \dagger$ G. AULING, ${ }^{2}$ M. DORSCH, ${ }^{3}$ E. STACKEBRANDT, ${ }^{3}$ AND L. I. SLY ${ }^{3}$ \\ Department of Animal Science, University of California, Davis, Davis, California 95616 ${ }^{1}$; Institut für \\ Mikrobiologie, Universität Hannover, 3000 Hannover 1, Germany ${ }^{2}$; and Centre for \\ Bacterial Diversity and Identification, Department of Microbiology,
}

The University of Queensland, Brisbane, Australia $4072^{3}$

\begin{abstract}
A recently isolated, selenate-respiring microorganism (strain $\mathbf{A X}^{\mathbf{T}}[\mathbf{T}=$ type strain]) was classified by using a polyphasic approach in which both genotypic and phenotypic characteristics were determined. Strain $\mathbf{A X}^{\mathbf{T}}$ is a motile, gram-negative, rod-shaped organism with a single polar flagellum. On the basis of phenotypic characteristics, this organism can be classified as a Pseudomonas sp. However, a comparison of the 16S rRNA sequence of strain $\mathrm{AX}^{\mathrm{T}}$ with the sequences of other organisms indicated that strain $\mathbf{A X}^{\mathrm{T}}$ is most similar to members of the beta subclass (level of similarity, 86.8\%) rather than to members of the gamma subclass (level of similarity, $\mathbf{8 0 . 2 \%}$ ) of the Proteobacteria. The presence of the specific polyamine 2-hydroxyputrescine and the presence of a ubiquinone with eight isoprenoid units in the side chain (ubiquinone Q-8) excluded strain $\mathbf{A X}^{\mathrm{T}}$ from the authentic genus Pseudomonas and allowed placement in the beta subclass of the Proteobacteria. Within the beta subclass, strain $\mathbf{A X}^{\mathrm{T}}$ is related to Iodobacter fluvatile. The phylogenetic distance (level of similarity, less than $\mathbf{9 0 \%}$ ), as well as a lack of common phenotypic characteristics between these organisms, prevents classification of strain $\mathbf{A X}^{\mathrm{T}}$ as a member of the genus Iodobacter. In addition, strain $\mathbf{A X}^{\mathrm{T}}$ possesses a unique mechanism for anaerobic respiration, which allows it to utilize selenate as an electron acceptor without interference by nitrate. Therefore, we propose that strain $\mathbf{A X}^{\mathrm{T}}$ should be the first member of a new genus and species, Thauera selenatis.
\end{abstract}

In the past, gram-negative, aerobic, rod-shaped bacteria with polar flagella have frequently been assigned to the genus Pseudomonas. The genetic heterogeneity of this genus became apparent when levels of rRNA cistron similarity were determined, which revealed the presence of several clusters of related organisms (28). These results were later confirmed by the results of the extensive DNA-DNA and DNA-rRNA hybridization studies of De Vos et al. (11-14) and by $16 \mathrm{~S}$ rRNA cataloging results $(41,43)$, which revealed that members of the genus Pseudomonas branch off within the alpha, beta, and gamma subclasses of the Proteobacteria (34). Only the members of the Pseudomonas fluorescens branch in the gamma subclass represent the authentic pseudomonads. As pointed out by Willems et al. (36), all of the other Pseudomonas species are considered to be misclassified. Chemotaxonomy provides a rapid alternative approach for excluding organisms from or including organisms in the authentic pseudomonad taxon on the basis of the results of fatty acid, ubiquinone, and polyamine analyses ( 1 , $2,8-10,27)$. Below, those organisms that have the genus name Pseudomonas, but are not part of the phylogenetic nucleus of the true pseudomonad taxon (see above) are indicated by enclosing the genus name in single quotation marks (e.g., 'Pseudomonas' cepacia).

In a polyphasic approach to bacterial systematics, genotypic and phenotypic properties are combined to delineate taxa, and it was not until recently that several species of the obviously heterogeneous taxon Pseudomonas were either

\footnotetext{
* Corresponding author.

† Present address: Department of Microbiology and Molecular Genetics, University of California, Los Angeles, Los Angeles, CA 90024-1489.
}

placed in other genera (e.g., the genera Xanthomonas [35] and Comamonas [13]) or elevated to genus rank (e.g., the genera Sphingomonas [44], Hydrogenophaga [36], and Acidovorax [38]) by using this approach.

The same polyphasic strategy was used in this study to classify an organism that was tentatively and incorrectly classified as a Pseudomonas strain (22). Only one strain of this organism has been isolated, and this strain has the unique characteristic of reducing selenate to selenite by anaerobic respiration.

\section{MATERIALS AND METHODS}

Media and growth conditions. The media which were used (defined minimal medium and minimal medium containing $0.4 \%$ yeast extract) have been described previously (22). Strain $\mathrm{AX}^{\mathrm{T}}(\mathrm{T}=$ type strain) was grown as described previously (22). This organism has been deposited with the American Type Culture Collection as strain ATCC $55363^{\mathrm{T}}$.

Bacterial strains tested for anaerobic growth with selenate or nitrate. Strains were obtained from the American Type Culture Collection (ATCC) and from the Culture Collection of the Department of Microbiology, University of Queensland, and were tested for the ability to grow by using selenate or nitrate for respiration in anaerobic ATCC media (16) containing 5 or $10 \mathrm{mM}$ selenate or $10 \mathrm{mM}$ nitrate (22). The following bacterial strains were obtained from the ATCC: Comamonas terrigena ATCC 8461 (tested in ATCC medium 386 containing glucose [final concentration, $2 \mathrm{~g} / \mathrm{li}$ ter]), Janthinobacterium lividum ATCC 12473 (tested in ATCC medium 3 containing glucose [final concentration, 2 g/liter]), Hydrogenophaga flava ATCC 33667 (tested in ATCC medium 1246 containing gluconate [final concentration, 2 g/liter]), Chromobacterium violaceum ATCC 12472 
(tested in ATCC medium 3 containing acetate [final concentration, $1.4 \mathrm{~g} /$ liter]), Iodobacter fluviatile ATCC 33051 (tested in ATCC medium 3 containing acetate [final concentration, $1.4 \mathrm{~g} /$ liter]), 'Pseudomonas' cepacia ATCC 25416 (tested in ATCC medium 3 containing acetate [final concentration, $1.4 \mathrm{~g} /$ liter]), Alcaligenes faecalis ATCC 8750 (tested in ATCC medium 3 containing gluconate [final concentration, $2 \mathrm{~g} /$ liter]), and Alcaligenes xylosoxydans subsp. $x y$ losoxydans ATCC 27061 (tested in ATCC medium 3 containing gluconate [final concentration, $2 \mathrm{~g} /$ liter]). The bacterial strains obtained from the Culture Collection of the Department of Microbiology, University of Queensland, were 'Pseudomonas' mixta UQM 1762 (= ATCC 49108) (tested in ATCC medium 416 containing sucrose [final concentration, $20 \mathrm{~g} / \mathrm{liter}]$ ), Acidovorax facilis UQM 1918 (= ATCC 11228) (tested in ATCC medium 72 containing glucose [final concentration, $2 \mathrm{~g} /$ liter]), Variovorax paradoxus UQM 1905 (= ATCC 17713) (tested in ATCC medium 3 containing acetate [final concentration, $1.4 \mathrm{~g} /$ liter]), and Derxia gumosa UQM 2144 (= ATCC 15994) (tested in ATCC medium 165 containing glucose [final concentration, $2 \mathrm{~g} /$ liter]).

Phenotypic characterization. The presence of oxidase, catalase, arginine dihydrolase, and lysine decarboxylase and the ability to hydrolyze starch and gelatin were determined as described by Smibert and Krieg (31). The presence of a diffusible, fluorescent pigment was determined by using King media A and B (28). The denitrification test was carried out in anaerobic minimal medium containing $0.4 \%$ yeast extract, $20 \mathrm{mM}$ nitrate, $20 \mathrm{mM}$ acetate, and a Durham tube; growth and gas production were recorded within $48 \mathrm{~h}$ after inoculation (31). The nature of the gas produced during denitrification was determined by using the method of Jenneman et al. (18). Strain $\mathrm{AX}^{\mathrm{T}}$ was grown for $48 \mathrm{~h}$ in an anaerobic chamber (Coy Laboratory Products, Inc., Ann Arbor, Mich.) on minimal medium containing 2\% agar, 20 $\mathrm{mM}$ acetate, $40 \mathrm{mM}$ nitrate, and $0.0001 \%$ resazurin. The production of $\mathrm{N}_{2} \mathrm{O}$ was detected by the formation of a pink color around the colonies, which was due to oxidation of the resazurin by $\mathrm{N}_{2} \mathrm{O} ; \mathrm{N}_{2}$ production does not cause the oxidation of resazurin.

The ability of strain $\mathrm{AX}^{\mathrm{T}}$ to use various carbon sources was tested on aerobic minimal medium containing $2 \%$ agar as described below. All substrates were prepared as $2 \mathrm{M}$ solutions or as saturated solutions $(0.18$ to $1.4 \mathrm{M})$ and were sterilized by filtration through sterile Acro Disc filters (pore size, $0.2 \mu \mathrm{m}$; diameter, $25 \mathrm{~mm}$; Gelman Sciences). Sterile Whatman no. 1 filter discs (diameter, $7 \mathrm{~mm}$ ) were saturated with each carbon source and were dropped onto a lawn of strain $\mathrm{AX}^{\mathrm{T}}$ spread on minimal agar medium containing no carbon source. The substrate diffused into the agar, and the cells grew at all concentrations up to the highest concentration that they could tolerate. Three discs were placed on each plate at equal distances from each other. To prepare the lawn of strain $\mathrm{AX}^{\mathrm{T}}$, the organism was grown overnight aerobically in minimal medium broth supplemented with 10 $\mathrm{mM}$ acetate. The culture was harvested by centrifugation at $8000 \times g$ for $30 \mathrm{~min}$ and washed once. The cells were suspended in 0.1 volume of minimal medium, and a $0.1-\mathrm{ml}$ portion was spread onto each minimal medium agar plate. The plates were incubated at $28^{\circ} \mathrm{C}$ and were examined each day by using a dissecting microscope during an incubation period of at least 7 days. On these plates the organisms formed haloes around the discs and growth was classified as good, moderate, or poor on the basis of the width and thickness of these haloes.

Growth on $\mathrm{H}_{2}-\mathrm{O}_{2}-\mathrm{CO}_{2}$ was determined in $10-\mathrm{ml}$ portions of minimal medium broth in closed $20 \mathrm{-ml}$ serum bottles; 10 $\mathrm{ml}$ of $\mathrm{H}_{2}$ and $10 \mathrm{ml}$ of air were added to the bottle after inoculation, and $\mathrm{CO}_{2}$ was supplied by the $\mathrm{HCO}_{3}{ }^{-}$present in the medium (22). Growth on methanol, isobutyrate, and propionate was tested in 10 -ml portions of minimal medium broth in closed roll tubes under a $100 \% \mathrm{~N}_{2}$ atmosphere (22). The following concentrations were used: methanol, 1 and 3 $\mathrm{mM}$; isobutyrate, $5 \mathrm{mM}$; propionate, $5 \mathrm{mM}$.

The agar method described above, which was used to test the range of substrates that could support growth of strain $\mathrm{AX}^{\mathrm{T}}$, was used for the following reasons: (i) with certain substrates, cells tended to lyse after growth ceased, and therefore, it was desirable not to do the tests in broth cultures; and (ii) neither the optimum concentrations nor the inhibitory concentrations of the substrates were known, and therefore, use of a concentration gradient permitted the organism to grow at the concentrations that best suited it.

DNA base composition. DNA was extracted and the melting temperature was determined by using the method of Nelson et al. (25), with some modifications. Strain $\mathrm{AX}^{\mathrm{T}}$ was grown aerobically on a shaker in $100 \mathrm{ml}$ of minimal medium containing $0.4 \%$ yeast extract, $20 \mathrm{mM}$ nitrate, and $20 \mathrm{mM}$ acetate. After $24 \mathrm{~h}$ of incubation at $28^{\circ} \mathrm{C}, 1 \mathrm{~g}$ (wet weight) of cells was collected by centrifugation at $10,000 \times g$ for 15 min. DNAs isolated from Escherichia coli and Pseudomonas putida were used as controls; both organisms were grown in nutrient broth (Difco) at $37^{\circ} \mathrm{C}$, and after $24 \mathrm{~h}$ of incubation, 2 $\mathrm{g}$ (wet weight) of cells was harvested by centrifugation at $10,000 \times g$ for $15 \mathrm{~min}$. All of the cells were broken by using a French press $\left(16,000 \mathrm{lb} / \mathrm{in}^{2}\right.$; Aminco Chance, Silver Spring, Md.). DNA from each resulting cell extract was isolated, and the melting temperature was determined and used to calculate the moles percent $\mathrm{G}+\mathrm{C}$ content as described by Nelson et al. (25).

Scanning electron microscopy. Strain $\mathrm{AX}^{\mathrm{T}}$ was grown at $28^{\circ} \mathrm{C}$ for 6 to $12 \mathrm{~h}$ in minimal medium supplemented with 10 $\mathrm{mM}$ acetate and $10 \mathrm{mM}$ nitrate. The cells either were filtered onto Nuclepore filters (pore size, $0.4 \mu \mathrm{m}$ ) and fixed in Sorenson buffer (17) containing $2.5 \%$ glutaraldehyde or were fixed by adding $2.5 \%$ glutaraldehyde to the medium and then filtered onto a Nuclepore filter. The fixed and filtered cells were washed in Sorenson buffer, dehydrated three times in a series consisting of increasing ethanol concentrations in water $(50,75,95$, and $100 \%$ [ $\mathrm{vol} / \mathrm{vol}]$ ethanol), critical point dried, mounted on a stub, gold coated in a sputter coater, and then viewed in the first stage of a model ISI DS130 scanning electron microscope (Topcon, Pleasanton, Calif.).

Phylogenetic analysis. All of the steps involved in sequence analysis of $16 \mathrm{~S}$ ribosomal DNA, including isolation of genomic DNA, amplification of 16 S ribosomal DNA, purification of polymerase chain reaction products, and subsequent sequence analysis of these products have been described in detail previously (29). A partial sequence consisting of 1,346 nucleotides was aligned with 57 homologous sequences from members of the alpha, beta, and gamma subclasses of the Proteobacteria (5a, 15, 24, 26). Positions 1 through 31 and 1376 through 1542 (E. coli nomenclature [42]) were omitted from the analysis. In order to include restricted information for about 150 nucleotides of the $16 \mathrm{~S}$ rRNAs from additional members of the beta subclass of the Proteobacteria $(6,9)$, all of the sequences of the reference organisms were shortened to the same length in an additional comparison. Equally weighted (Hamming distances) and percent similarities between each pair of sequences were calculated. The phylogenetic analysis was carried out by using the neighborliness method (30). The 
TABLE 1. Percent similarity between one 1,358-nucleotide-long stretch of the 16S ribosomal DNA sequences of strain $\mathrm{AX}^{\mathrm{T}}$ and other members of the beta subclass of the Proteobacteria (8) (above the diagonal) and equally weighted (Hamming) distances between the $16 \mathrm{~S}$ ribosomal DNA sequences (below the diagonal)

\begin{tabular}{|c|c|c|c|c|c|c|c|c|c|c|c|c|c|c|}
\hline Organism & 墨芯 & 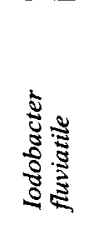 & 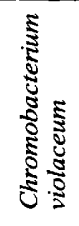 & 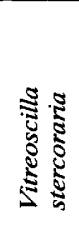 & 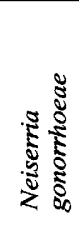 & 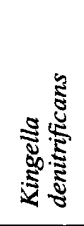 & 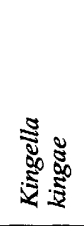 & 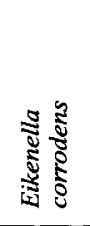 & 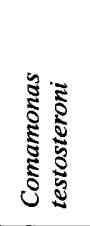 & 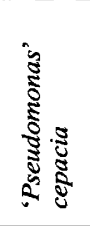 & 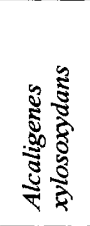 & 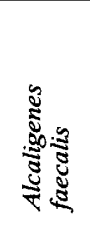 & 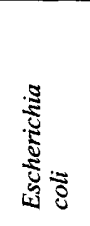 & 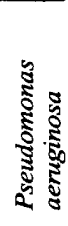 \\
\hline Strain $\mathrm{AX}^{\mathrm{T}}$ & & 88.7 & 87.7 & 86.3 & 85.4 & 87.6 & 85.6 & 87.0 & 85.1 & 87.6 & 86.2 & 85.5 & 79.1 & 83.6 \\
\hline Iodobacter fluviatile & 154 & & 90.3 & & 86.7 & 88.1 & 87.2 & 88.1 & & 88.7 & 89.2 & 87.9 & 80.7 & 83.7 \\
\hline Chromobacterium violaceum & 167 & 132 & & 89.3 & 88.1 & 91.2 & 89.5 & 91.5 & 86.5 & 88.2 & 88.4 & 86.8 & 80.0 & 82.6 \\
\hline Vitreoscilla stercoraria & 186 & 163 & 145 & & 91.4 & 90.6 & 90.1 & 91.8 & 85.2 & 86.5 & 86.5 & 86.8 & 81.9 & 82.0 \\
\hline Neisseria gonorrhoeae & 198 & 181 & 162 & 117 & & 91.9 & 91.5 & 91.7 & 82.8 & 85.8 & 86.2 & 85.3 & 80.7 & 81.2 \\
\hline Kingella denitrificans & 168 & 161 & 119 & 128 & 110 & & 93.9 & 95.8 & 85.0 & 86.9 & 86.7 & 87.3 & 81.5 & 82.8 \\
\hline Kingella kingae & 196 & 174 & 143 & 135 & 116 & 83 & & 93.3 & 83.9 & 86.5 & 85.8 & 85.9 & 79.7 & 80.9 \\
\hline Eikenella corrodens & 177 & 162 & 116 & 112 & 113 & 58 & 92 & & 84.8 & 86.7 & 87.0 & 87.4 & 80.3 & 82.0 \\
\hline Comamonas testosteroni & 203 & 164 & 183 & 201 & 234 & 205 & 219 & 207 & & 87.3 & 87.7 & 85.6 & 80.1 & 81.7 \\
\hline 'Pseudomonas' cepacia & 169 & 154 & 160 & 183 & 193 & 178 & 184 & 180 & 172 & & 89.2 & 88.5 & 79.2 & 82.3 \\
\hline Alcaligenes xylosoxydans & 187 & 146 & 158 & 184 & 188 & 181 & 193 & 177 & 167 & 147 & & 92.4 & 79.5 & 81.6 \\
\hline Alcaligenes faecalis & 197 & 164 & 179 & 179 & 200 & 173 & 192 & 171 & 196 & 156 & 103 & & 80.2 & 81.1 \\
\hline Escherichia coli & 284 & 262 & 272 & 246 & 262 & 251 & 276 & 267 & 270 & 283 & 278 & 269 & & 82.5 \\
\hline Pseudomonas aeruginosa & 223 & 221 & 236 & 244 & 255 & 233 & 260 & 244 & 249 & 240 & 250 & 256 & 237 & \\
\hline
\end{tabular}

algorithm was implemented as part of the program package SAGE (Technoma GmbH, Heidelberg, Germany).

Chemotaxonomic analysis. Quinones were extracted and analyzed as described by Auling et al. (3). Extraction, analysis, and quantification of polyamines were carried out as described by Busse and Auling (10).

Nucleotide sequence accession number. The rRNA sequence of strain $\mathrm{AX}^{\mathrm{T}}$ has been deposited in the EMBL data bank under accession number X68491.

\section{RESULTS AND DISCUSSION}

Phylogeny. The average similarity values for the $16 \mathrm{~S}$ rRNA sequences of strain $\mathrm{AX}^{\mathrm{T}}$ and representatives of the alpha, beta, and gamma subclasses of the Proteobacteria range from 73.0 to $76.8 \%$ (average, $75.4 \%$ ), 85.1 to $88.7 \%$ (average, $86.8 \%$ ), and 77.5 to $82.2 \%$ (average, $80.2 \%$ ), respectively. Consequently, strain $\mathrm{AX}^{\mathrm{T}}$ can be considered a member of the beta subclass (Table 1). This placement is supported by the findings that the polyamines 2-hydroxyputrescine and putrescine, as well as ubiquinone Q-8, are present in strain $\mathrm{AX}^{\mathrm{T}}$ cells (Table 2). 2-Hydroxyputrescine is the specific polyamine of the beta subclass of the Proteobacteria (10). Ubiquinone Q-8 is the major quinone compound in members of the beta subclass of the Proteobacteria (9), whereas ubiquinone Q-9 is characteristic of the authentic pseudomonads (8).

A phylogenetic analysis was carried out between strain $\mathrm{AX}^{\mathrm{T}}$ and members of the beta subclass of the Proteobacteria for which 16S rRNA and DNA data are listed in the Ribosome RNA Database Project, as well as 'Pseudomonas' mixta, Pseudomonas chitinolytica, Pseudomonas pickettii, Pseudomonas solanacearum, Pseudomonas andropogonis, Pseudomonas caryophilli, and Pseudomonas gladioli (unpublished data). The phylogenetic distance between strain $\mathrm{AX}^{\mathrm{T}}$ and each of these organisms, including representatives of the genera Rhodocyclus, Alcaligenes, Chromobacterium, Iodobacter, Spirillum, Neisseria, Eikenella, Kingella, Simonsiella, and Vitreoscilla, nonauthentic pseudomonads, and ammonium-oxidizing organisms, was less than $90 \%$. Strain
TABLE 2. Biochemical and physiological characteristics of $T$. selenatis ${ }^{a}$

\begin{tabular}{|c|c|}
\hline Characteristic & T. selenatis \\
\hline \multicolumn{2}{|c|}{ 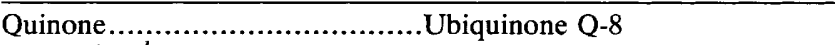 } \\
\hline 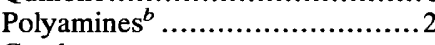 & putrescine, putrescine \\
\hline Catalase & + \\
\hline Oxidase & + \\
\hline Arginine dehydrolase $\ldots \ldots \ldots \ldots \ldots$ & - \\
\hline Lysine decarboxylase ................ & - \\
\hline 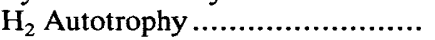 & + \\
\hline Denitrification to $\mathrm{N}_{2} \mathrm{O} \ldots \ldots \ldots \ldots \ldots . . . . .$. & + \\
\hline Selenate respiration $\ldots \ldots \ldots \ldots \ldots \ldots$ & + \\
\hline \multicolumn{2}{|l|}{ Poly- $\beta$-hydorxybutyrate } \\
\hline accumulation .......................... & + \\
\hline 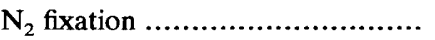 & - \\
\hline \multicolumn{2}{|l|}{ Hydrolysis of: } \\
\hline Gelatin & - \\
\hline 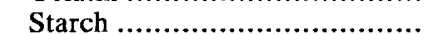 & - \\
\hline Growth factors required ${ }^{c} . . . . . . . . . .$. & + \\
\hline
\end{tabular}

${ }^{a}$ In carbon source utilization tests performed on minimal medium containing $2 \%$ agar (see text), good growth occurred with the following carbon sources: acetate, alanine, arginine, aspartate, benzoate, D-amino- $N$-butyrate, 3-hydroxybutyrate, isobutyrate, citrate, fructose, glutamate, lactate, lactose, proline, propionate, pyruvate, serine, succinate, sucrose, Tween 40 , Tween 80 , and $\mathrm{H}_{2}-\mathrm{O}_{2}-\mathrm{CO}_{2}$. Moderate growth occurred with $p$-anisate, asparagine, ferulate, fucose, hydroxyproline, lactulose, leucine, maltose, raffinose, phenylacetate, veratrate, and glucose. Poor growth occurred with cis-aconitate, $p$-aminobenzoate, arabinose, erythritol, formate, galactose, D-galacturonate, gentiobiose, DL- $\alpha$-glycerophosphate, histidine, hydroxycinnamate, $m$-inositol, mannose, 3-phenylpropanoate, phenoxyacetate, phenylalanine, rhamnose, sorbitol, trehalose, turanose, and vanillin. And no growth occurred with $\mathrm{L}$-alanylglycine, $m$-anisate, catechol, ethyl vanillin, $\alpha$-Ketoglutarate, glycerol, $o$-methyoxyphenoxyacetate, and methanol.

${ }^{b}$ The concentrations of the polyamines were as follows: 2-hydroxyputrescine, $33.1 \mu \mathrm{mol} / \mathrm{mg}$ (dry weight) of cells; putrescine, $68.9 \mu \mathrm{mol} / \mathrm{mg}$ (dry weight) of cells.

$c$ The vitamins added to support growth were folic acid, riboflavin, thiamine hydrochloride, pantothenate, niacinamide, vitamin $B_{12}$, biotin, pyridoxine hydrochloride, and $p$-aminobenzoate (22). 
TABLE 3. Characteristics that differentiate Thauera selenatis gen. nov., sp. nov., from taxa that have similar DNA base compositions and belong to the beta subclass of the Proteobacteria

\begin{tabular}{|c|c|c|c|c|c|c|}
\hline Characteristic & $\begin{array}{l}\text { 'Pseudomonas' } \\
\text { mixta }\end{array}$ & $\begin{array}{l}\text { Pseudomonas solanacearum } \\
\text { rRNA branch }\end{array}$ & Comamonas $^{c}$ & Acidovorax ${ }^{c}$ & Hydrogenophaga ${ }^{c}$ & Variovorax ${ }^{c}$ \\
\hline Cell morphology & Rods & Rods & Rods or spirilla & Rods & Rods & Rods \\
\hline \multicolumn{7}{|l|}{ Flagellation } \\
\hline Polar & $t^{i}$ & + & - & + & + & - \\
\hline Lateral & + & - & - & - & - & - \\
\hline Bipolar tufts & - & - & + & - & - & - \\
\hline Peritrichous & - & - & - & - & - & + \\
\hline Yellow nondiffusible pigment & - & - & - & - & + & + \\
\hline Starch hydrolysis & + & $\mathrm{D}^{i}$ & - & - & - & - \\
\hline Occurrence $^{l}$ & $\mathbf{S}$ & S, FW, CS, IP & $\mathrm{S}, \mathrm{FW}, \mathrm{CS}, \mathrm{IP}$ & $\mathrm{S}, \mathrm{FW}, \mathrm{CS}$ & $\mathrm{S}, \mathrm{FW}$ & S, FW \\
\hline Growth on nutrient agar & - & + & + & + & + & + \\
\hline Tolerance to $1.5 \% \mathrm{NaCl}$ & - & + & + & $\mathrm{d}$ & + & + \\
\hline Chemolithic growth on $\mathrm{H}_{2}$ & - & - & - & d & + & d \\
\hline Nitrogen fixation & - & - & - & - & - & - \\
\hline Denitrification & - & $\mathrm{D}$ & & D & $+^{m}$ & $-^{m}$ \\
\hline Selenate respiration ${ }^{m}$ & - & $\mathrm{ND}^{n}$ & - & - & - & - \\
\hline Oxidative metabolism & + & + & + & + & + & + \\
\hline \multicolumn{7}{|l|}{ Utilization of: } \\
\hline D-Glucose & + & + & - & + & + & + \\
\hline Lactose & $\mathrm{d}$ & - & - & - & - & - \\
\hline Inulin & + & - & - & - & - & - \\
\hline Acetate & - & + & + & + & + & + \\
\hline Propionate & - & + & + & d & d & $\mathrm{d}$ \\
\hline Isobutyrate & - & $+^{o}$ & + & d & - & d \\
\hline meso-Inositol & - & $+^{p}$ & d & - & + & d \\
\hline Sorbitol & - & $+^{p}$ & - & d & + & + \\
\hline DL-4-Aminobutyrate & - & + & d & + & - & + \\
\hline$\beta$-Alanine & - & + & $\mathrm{d}$ & + & - & + \\
\hline L-Proline & - & + & + & + & + & + \\
\hline $\mathrm{G}+\mathrm{C}$ content $(\mathrm{mol} \%)$ & $67-70$ & $64-70$ & $60-69$ & $62-66$ & $67-69$ & $65-69$ \\
\hline
\end{tabular}

b Data from reference 28

${ }^{c}$ Data from references 28 and 36 through 40.

d Data from reference 4.

e Data from references 32 and 33

${ }^{f}$ Data from reference 20 (including data for Aquaspirillum anulus, Aquaspirillum delicatus, Aquaspirillum giesbergeri, Aquaspirillum gracile, Aquaspirillum metamorphum, Aquaspirillum psychrophilum, and Aquaspirillum sinosum).

${ }^{g}$ Data from references 21 and 23.

${ }^{h}$ Data from references 7 and 19.

${ }^{i}+$, positive; - , negative; D, variable among the species of a genus; $d, 11$ to $89 \%$ of the strains are positive; (w), weak.

${ }^{j}$ Produces violacein.

${ }^{k}$ Colonies are brownish on minimal agar medium containing $0.4 \%$ yeast extract.

${ }^{l}$ Abbreviations: S, soil; FW, fresh water; CS, clinical samples; IP, infected plants.

${ }^{m}$ Results for the type species only.

${ }^{n} \mathrm{ND}$, not determined (pathogens not available from the ATCC in accordance with a U.S. Department of Agriculture decision).

${ }^{\circ}$ Isobutyrate was not utilized by Pseudomonas caryophylli.

${ }^{p}$ meso-Inositol and sorbitol were not utilized by Pseudomonas mallei.

$\mathrm{AX}^{\mathrm{T}}$ exhibits the highest degree of relatedness with $I$. fluviatile ATCC $33051(88.7 \%)$. This relationship is confirmed by the position of the new isolate in the phylogenetic tree (Fig. 1). The phylogenetic distance between strain $\mathrm{AX}^{\mathrm{T}}$ and $I$. fluviatile (level of similarity, less than $90 \%$ ) and the lack of common phenotypic characteristics (Table 3 ) indicate that these two organisms are not members of the same genus. The branching order of the reference strains is almost identical to the topology of the tree published previously (15).

Although strain $\mathrm{AX}^{\mathrm{T}}$ is Pseudomonas-like in morphology and many phenotypic characteristics, no close genomic relatedness exists between this strain and the true pseudomonads (i.e., organisms belonging to the gamma subclass) or even between this strain and 'Pseudomonas' cepacia (a member of the beta subclass and not a true pseudomonad). Also, the results of an analysis of a short stretch of the 16S rRNAs from 29 members of the beta subclass, as well as Pseudomonas aeruginosa, 'Pseudo- monas' mixta, a number of Pseudomonas isolates (9), and members of the genus Hydrogenophaga (formerly members of the genus Pseudomonas) (6), support the conclusion that strain $\mathrm{AX}^{\mathrm{T}}$ should not be considered a member of one of the several subgroups of nonauthentic Pseudomonas species (data not shown).

Growth characteristics. Strain $\mathrm{AX}^{\mathrm{T}}$ grew in minimal medium only when it was supplemented with vitamins (Table 2). This organism can grow aerobically or anaerobically with nitrate or selenate as the terminal electron acceptor (22). The generation time for growth in minimal medium broth for all electron acceptors was about $170 \mathrm{~min}$.

Colonies on minimal medium containing $2 \%$ agar after 5 days of aerobic growth at $28^{\circ} \mathrm{C}$ were small (diameter, 0.75 $\mathrm{mm}$ ), round with entire edges, and convex. The colonies were light brown and adhered to the agar. Colonies grown aerobically on agar supplemented with $0.4 \%$ yeast extract were $1.1 \mathrm{~mm}$ in diameter after 3 days of incubation. 
TABLE 3-Continued

\begin{tabular}{|c|c|c|c|c|c|c|c|}
\hline Xylophilus ${ }^{c}$ & Derxia $^{d}$ & Janthinobacterium ${ }^{e}$ & Aquaspirillum $f$ & $\begin{array}{c}\text { Chromobacterium } \\
\text { violaceum }^{e}\end{array}$ & I. fluviatile & $\begin{array}{l}\text { Alcaligenes faecalis and } \\
\text { Alcaligenes xylosoxydans }\end{array}$ & T. selenatis \\
\hline Rods & Rods & Rods & $\begin{array}{c}\text { Helices } \\
\text { (clockwise) }\end{array}$ & Rods & Rods & Rods and cocci & Rods \\
\hline+ & + & + & - & + & + & - & + \\
\hline- & - & + & - & + & + & - & - \\
\hline- & - & - & + & - & - & - & - \\
\hline $\bar{t}$ & - & - & - & - & $z_{j}$ & $\begin{array}{l}+ \\
-\end{array}$ & $t^{k}$ \\
\hline$d^{i}$ & - & - & - & $-(\mathbf{w})^{i}$ & - & - & - \\
\hline IP & $\mathrm{s}$ & S, FW & FW & $\mathrm{S}, \mathrm{FW}$ & FW & $\mathrm{S}, \mathrm{FW}, \mathrm{CS}$ & FW \\
\hline- & - & + & - & + & + & + & - \\
\hline - & + & + & - & + & + & - & $\begin{array}{l}+ \\
+\end{array}$ \\
\hline \multirow{2}{*}{-} & ${ }_{-m}^{+}$ & $d$ & - & $-^{m}$ & $-m$ & + & $\bar{t}$ \\
\hline & - & - & - & - & $=$ & $\begin{array}{ll}+ \\
\pm\end{array}$ & $\begin{array}{lll}+ \\
+\end{array}$ \\
\hline+ & + & + & + & D & - & + & + \\
\hline \multirow[t]{2}{*}{+} & + & + & D & & & D & + \\
\hline & - & $\bar{d}$ & & & & - & + \\
\hline - & - & d & d & d & - & + & + \\
\hline - & - & & - & & & + & + \\
\hline \multirow{4}{*}{-} & & + & - & & & $\underline{D}$ & $\begin{array}{l}+ \\
+(w)\end{array}$ \\
\hline & + & + & & & & - & $\begin{array}{l}+(w) \\
+(w)\end{array}$ \\
\hline & & & & & & $\mathrm{D}$ & + \\
\hline & & & $\mathrm{D}$ & $\stackrel{+}{d}$ & & $\begin{array}{l}\text { D } \\
+\end{array}$ & $\begin{array}{llll}+ & & l & -1\end{array}$ \\
\hline $68-69$ & $69-72$ & $61-67$ & $57-65$ & $65-68$ & $50-52$ & $56-70$ & 66 \\
\hline
\end{tabular}

The organism was able to grow on many different carbon sources and also chemolitotrophically with $\mathrm{H}_{2}-\mathrm{CO}_{2}-\mathrm{O}_{2}$ (air) (Table 3 ). When strain $\mathrm{AX}^{\mathrm{T}}$ was grown with acetate, poly$\beta$-hydroxybutyrate was accumulated (Table 2) (22).

Morphological characteristics. The cells were gram negative and rod shaped $(1.4$ by $0.56 \mu \mathrm{m}$ ) with rounded ends (Fig. 2). The cells were motile by means of a single polar flagellum (Fig. 2).

Biochemical and physiological characteristics. The bio-

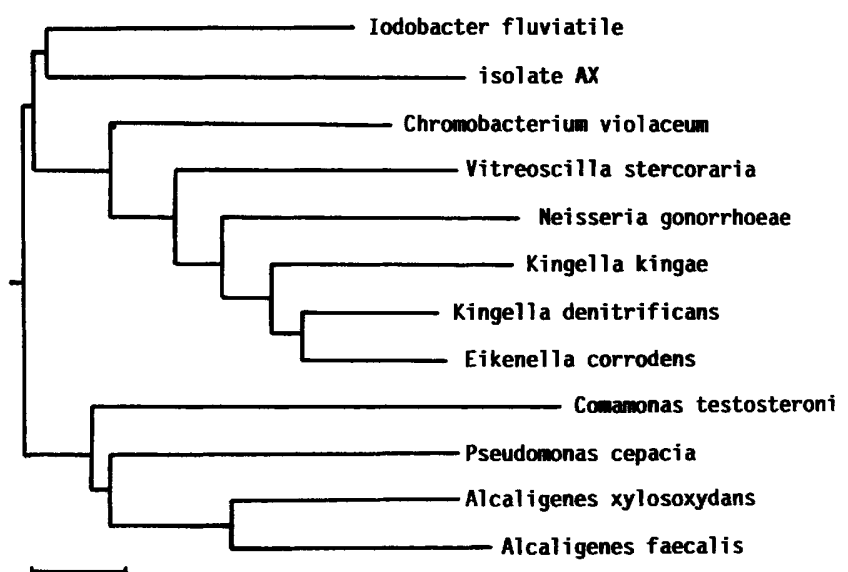

FIG. 1. Phylogenetic position of strain $\mathrm{AX}^{\mathrm{T}}$ among members of the beta subclass of the Proteobacteria. Bar $=20$ nucleotide exchanges. chemical and physiological characteristics of strain $\mathrm{AX}^{\mathrm{T}}$ are shown in Tables 2 and 3.

Taxonomic position. The polyphasic characterization of strain $\mathrm{AX}^{\mathrm{T}}$ showed that this organism could not be assigned to any currently recognized genus on the basis of phenotypic characteristics and the results of a phylogenetic analysis of $16 \mathrm{~S}$ rRNA sequences. In addition, this organism possesses a unique mechanism for anaerobic respiration, because it utilizes selenate $\left(\mathrm{SeO}_{4}{ }^{2-} ; \mathrm{Se}^{\mathrm{VI}}\right)$ as the terminal electron acceptor.

Strain $\mathrm{AX}^{\mathrm{T}}$ is the only member of a single line of descent within the beta subclass of the Proteobacteria and can be differentiated phenotypically from taxa with similar DNA base compositions (Table 3), including its closest phylogenetic relatives, $I$. fluviatile and Chromobacterium violaceum (Fig. 1 and Table 3). None of the organisms tested that belonged to the beta subclass of the Proteobacteria was able to grow anaerobically by using $\mathrm{SeO}_{4}{ }^{2-}$ as the terminal electron acceptor (Table 3).

Consequently, we propose that strain $\mathrm{AX}^{\mathrm{T}}$ should be the first member of a new genus and new species, Thauera selenatis.

Description of the genus Thauera gen. nov. Thauera (Thau'e.ra. N. L. fem. n. Thauera, in honor of R. Thauer). Gram-negative, rod-shaped cells are $1.4 \mu \mathrm{m}$ long by $0.56 \mu \mathrm{m}$ wide, have rounded ends, and contain poly- $\beta$-hydroxybutyrate inclusions. Cells are motile, and each cell has a single polar flagellum. Oxidative metabolism. Contains ubiquinone Q-8. Grows aerobically in defined media containing acetate as the carbon source and electron donor. Under anaerobic conditions exhibits anaerobic respiration with selenate or 


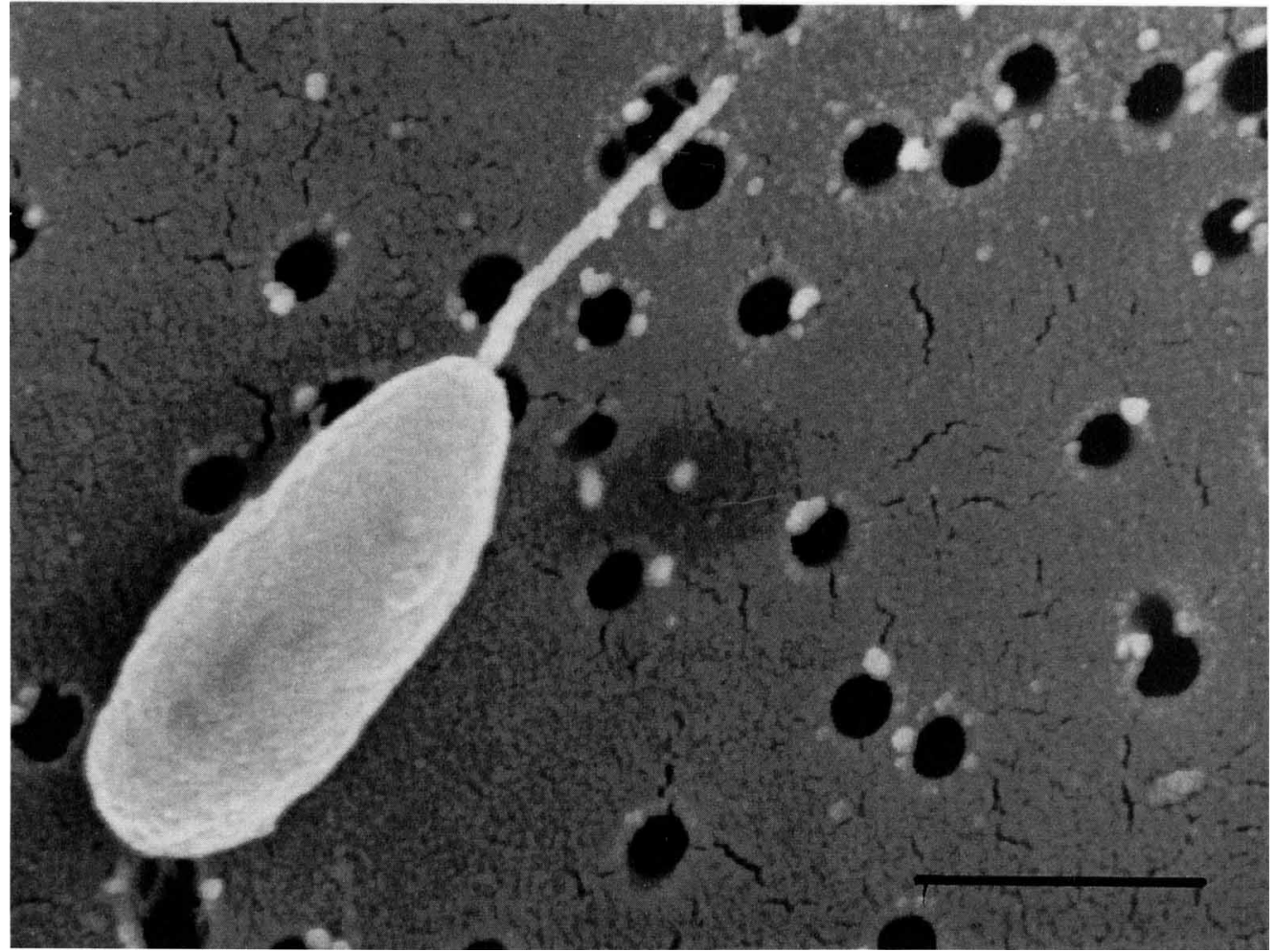

FIG. 2. Scanning electron micrograph of strain $\mathrm{AX}^{\mathrm{T}}$ grown anaerobically in minimal medium supplemented with $10 \mathrm{mM}$ acetate and $10 \mathrm{mM}$ nitrate. Bar $=1 \mu \mathrm{m}$.

nitrate as the electron acceptor. Nitrate is reduced to $\mathrm{N}_{2} \mathrm{O}$. Selenate is reduced to selenite. Acetate is metabolized to $\mathrm{CO}_{2}$. Growth is also supported by the carbon and energy sources alanine, arginine, aspartate, benzoate, $D$-amino- $N$ butyrate, 3-hydroxybutyrate, isobutyrate, citrate, fructose, glutamate, lactate, lactose, proline, propionate, pyruvate, serine, succinate, and sucrose. Less vigorous growth occurs with glucose. No growth occurs on nutrient agar (Difco). Vitamins are required for growth in defined media. Colonies are small, round with entire edges, convex, adherent, and light brown. Optimal growth occurs at 25 to $30^{\circ} \mathrm{C}$. The optimal $\mathrm{pH}$ for growth with nitrate is $\mathrm{pH} 8$, and the optimal $\mathrm{pH}$ for growth with selenate is $\mathrm{pH} 7$. Grows autotrophically with hydrogen, carbon dioxide, and air. Unable to fix dinitrogen. Catalase and oxidase positive. Arginine dihydrolase is absent. The major polyamines are putrescine and 2-hydroxyputrescine. Phylogenetically, the genus is a member of the beta subclass of the Proteobacteria. The base composition of the DNA of the type strain of the type species is $66 \mathrm{~mol} \% \mathrm{G}+\mathrm{C}$ (as determined by the thermal denaturation method). The type species is Thauera selenatis.

Description of Thauera selenatis sp. nov. Thauera selenatis (se.le.na'tis. N.L. chem. term selenas, selenate; N.L. gen. $\mathrm{n}$. selenatis, of selenate, because the organism reduces selenate to selenite). In addition to the characteristics given above in the genus description, $T$. selenatis has the characteristics described below. Colonies on defined medium containing acetate are $0.75 \mathrm{~mm}$ in diameter after 5 days of aerobic growth at $28^{\circ} \mathrm{C}$. On agar supplemented with $0.4 \%$ yeast extract colonies are $1.1 \mathrm{~mm}$ in diameter after 3 days. Growth occurs at $4^{\circ} \mathrm{C}$ but not at $39^{\circ} \mathrm{C}$. Does not hydrolyze gelatin or starch. The DNA base composition of the type strain is $66 \mathrm{~mol} \% \mathrm{G}+\mathrm{C}$ (as determined by the thermal denaturation method). Other characteristics are shown in Tables 2 and 3.

The type strain is strain AX (= ATCC 55363), which was isolated from selenium-contaminated drainage water in the San Joaquin Valley of California.

\section{ACKNOWLEDGMENTS}

We thank T. MacAdoo (Department of Foreign Languages and Literature, Virginia Polytechnic Institute and State University) for advice concerning the correct name of the organism. We also thank M. Dunlap (Facility for Advanced Instrumentation, University of California, Davis) for taking the scanning electron micrographs, S. Lawson for technical assistance, and D. Nelson for assistance with determining the moles percent $\mathrm{G}+\mathrm{C}$ content of the DNA. We thank Daniela Ziegler and Klaus Blasczyk for analysis of the quinones and polyamines.

\section{REFERENCES}

1. Auling, G. The pseudomonads. In H.-J. Rehm and G. Reed (ed.), Biotechnology, vol. 1, 2nd ed., in press. Verlag Chemie, Weinheim, Germany.

2. Auling, G., H.-J. Busse, F. Pilz, L. Webb, H. Kneifel, and D. Claus. 1991. Rapid differentiation by polyamine analysis of Xanthomonas from phytopathogenic pseudomonads and other members of Proteobacteria interacting with plants. Int. J. Syst. Bacteriol. 41:223-228.

3. Auling, G., A. Probst, and R. M. Kroppenstedt. 1986. Chemotaxonomic and molecular taxonomy of $\mathrm{D}(-)$-tartrate-utilizing pseudomonads. Syst. Appl. Microbiol. 8:114-120.

4. Becking, J. H. 1984. Genus Derxia Jensen, De and Bhattacharya 1969 , p. 321-325. In N. R. Krieg and J. G. Holt (ed.), Bergey's manual of systematic bacteriology, vol. 1. The Williams \& Wilkins Co., Baltimore.

5. Bowman, J. P., L. I. Sly, and A. C. Hayward. 1988. Pseudo- 
monas mixta sp. nov., a bacterium from soil with degradative activity on a variety of complex polysaccharides. Syst. Appl. Microbiol. 11:53-59.

5a.Bowman, J. P., E. Stackebrandt, and L. I. Sly. Unpublished data.

6. Busse, H.-J. 1990. Chemotaxonomische und phylogenetische Charakterisierung von Schadstoffe abbauenden Gram-negativen Mikroorganismen. Ph.D. thesis. University of Hannover, Hannover, Germany.

7. Busse, H.-J., and G. Auling. 1992. The genera Alcaligenes and "Achromobacter", p. 2542-2555. In A. Balows, H.-G. Trüper, M. Dworkin, W. Harder, and K.-H. Schleifer (ed.), The prokaryotes. A handbook on the biology of bacteria: ecophysiology, isolation, identification, applications, 2nd ed. SpringerVerlag, New York.

8. Busse, H.-J., T. El-Banna, and G. Auling. 1989. Evaluation of different approaches for identification of xenobiotic-degrading pseudomonads. Appl. Environ. Microbiol. 55:1578-1583.

9. Busse, H.-J., T. El-Banna, H. Oyaizu, and G. Auling. 1992. Identification of xenobiotic-degrading isolates from the beta subclass of the Proteobacteria by a polyphasic approach including 16S rRNA partial sequencing. Int. J. Syst. Bacteriol. 42:1916.

10. Busse, H. J., and G. Auling. 1988. Polyamine pattern as a chemotaxonomic marker within the Proteobacteria. Syst. Appl. Microbiol. 11:1-8.

11. De Vos, P., and J. De Ley. 1983. Intra- and intergeneric similarities of Pseudomonas and Xanthomonas ribosomal ribonucleic acid cistrons. Int. J. Syst. Bacteriol. 33:487-509.

12. De Vos, P., M. Goor, M. Gillis, and J. De Ley. 1985. Ribosomal ribonucleic acid cistron similarities of phytopathogenic Pseudomonas species. Int. J. Syst. Bacteriol. 35:169-184.

13. De Vos, P., K. Kersters, E. Falsen, B. Pot, M. Gillis, P. Segers, and J. De Ley. 1985. Comamonas Davis and Park 1962 gen. nov. rev. emend., and Comamonas terrigena Hugh 1962 sp. nom. rev. Int. J. Syst. Bacteriol. 35:443-453.

14. De Vos, P., A. Van Landschoot, P. Segers, R. Tytgat, M. Gillis, M. Bauwens, R. Rossau, M. Goor, B. Pot, K. Kersters, P. Lizzarag, and J. De Ley. 1989. Genotypic relationships and taxonomic localization of unclassified Pseudomonas and Pseudomonas-like strains by deoxyribonucleic acid-ribosomal ribonucleic acid hybridizations. Int. J. Syst. Bacteriol. 39:3549.

15. Dewhirst, F. E., B. J. Paster, and P. L. Bright. 1989. Chromobacterium, Eikenella, Kingella, Neisseria, Simonsiella, and Vitreoscilla species comprise a major branch of the beta group Proteobacteria by $16 S$ ribosomal ribonucleic acid sequence comparison: transfer of Eikenella and Simonsiella to the family Neisseriaceae (emend.). Int. J. Syst. Bacteriol. 39:258-266.

16. Gherna, R., P. Pienta, and R. Cote (ed.). 1989. American Type Culture Collection Catalogue of Bacteria and Phages, 17th ed. American Type Culture Collection, Rockville, Md.

17. Glauert, A. 1975. Practical methods in electron microscopy, fixation, dehydration and embedding of biological specimens. American Elsevier Publishing Co., New York.

18. Jenneman, G. E., A. Montgomery, and M. J. McInerney. 1986. Method for detection of microorganisms that produce gaseous nitrogen oxides. Appl. Environ. Microbiol. 51:776-780.

19. Kerstens, K., and J. De Ley. 1984. Genus Alcaligenes Castellani and Chalmers 1919, p. 361-373. In N. R. Krieg and J. G. Holt (ed.), Bergey's manual of systematic bacteriology, vol. 1. The Williams \& Wilkins Co., Baltimore.

20. Krieg, N. R. 1984. Genus Aquaspirillum Hylemon, Wells, Krieg and Jannasch 1973, p. 72-90. In N. R. Krieg and J. G. Holt (ed.), Bergey's manual of systematic bacteriology, vol. 1. The Williams \& Wilkins Co., Baltimore.

21. Logan, N. A. 1989. Numerical taxonomy of violet-pigmented, gram-negative bacteria and description of Iodobacter fiuviatile gen. nov., comb. nov. Int. J. Syst. Bacteriol. 39:450-456.

22. Macy, J. M., T. A. Michel, and D. G. Kirsch. 1989. Selenate reduction by a Pseudomonas species: a new mode of anaerobic respiration. FEMS Microbiol. Lett. 61:195-198.

23. Moss, M. O., C. Ryall, and N. A. Logan. 1978. The classification and characterization of chromobacteria from a lowland river. J Gen. Microbiol. 105:11-21.

24. Neefs, J. M., Y. Van de Peer, L. Hendriks, and R. De Wachter. 1990. Compilation of small ribosomal subunit RNA sequences. Nucleic Acids Res. 18:2237-2317.

25. Nelson, D. C., J. B. Waterbury, and H. W. Jannasch. 1984. DNA base composition and genome size of the prokaryotic symbiont in Riftia pachyptila (Pogonophora). FEMS Microbiol. Lett. 24:267-271.

26. O'Connor, S. P., M. Dorsch, A. G. Steigerwalt, D. J. Brenner, and E. Stackebrandt. 1991. 16S rRNA sequences of Bartonella bacilliformis and cat scratch disease bacillus reveal phylogenetic relationships with the alpha-2 subgroup of the class Proteobacteria. J. Clin. Microbiol. 29:2144-2150.

27. Oyaizu, H., and K. Komagata. 1983. Grouping of Pseudomonas species on the basis of cellular fatty acid composition and the quinone system with special reference to the existence of 3-hydroxy fatty acids. J. Gen. Appl. Microbiol. 29:17-40.

28. Palleroni, N. J. 1984. Genus I. Pseudomonas Migula 1894, p. 141-219. In N. R. Krieg and J. G. Holt (ed.), Bergey's manual of systematic bacteriology, vol. 1. The Williams \& Wilkins Co., Baltimore.

29. Rainey, F., M. Dorsch, H. W. Morgan, and E. Stackebrandt. 1992. 16S rDNA analysis of Spirochaeta thermophila: its phylogenetic position and implications for the systematics of the order Spirochaetales. Syst. Appl. Microbiol. 15:197-202.

30. Sattath, S., and A. Tversky. 1977. Additive similarity trees. Psychometrika 42:319-345.

31. Smibert, R. M., and N. R. Krieg. 1981. General characterization, p. 411-449. In P. Gerhardt, R. G. E. Murray, R. N. Costilow, E. W. Nester, W. A. Wood, N. R. Krieg, and G. B. Phillips (ed.), Manual of methods for general microbiology. American Society for Microbiology, Washington, D.C.

32. Sneath, P. H. A. 1984. Genus Janthinobacterium De Ley, Segers and Gillis 1974, p. 376-377. In N. R. Krieg and J. G. Holt (ed.), Bergey's manual of systematic bacteriology, vol. 1. The Williams \& Wilkins Co., Baltimore.

33. Sneath, P. H. A. 1984. Genus Chromobacterium Bergonzini 1881 , p. 580-582. In N. R. Krieg and J. G. Holt (ed.), Bergey's manual of systematic bacteriology, vol. 1. The Williams \& Wilkins Co., Baltimore.

34. Stackebrandt, E., R. G. E. Murray, and H. G. Trüper. 1988. Proteobacteria classis nov., name for the phylogenetic taxon that includes the "purple bacteria and their relatives." Int. J. Syst. Bacteriol. 38:321-325.

35. Swings, J., P. De Vos, M. Van Den Mooter, and J. De Ley. 1983. Transfer of Pseudomonas maltophilia Hugh 1981 to the genus Xanthomonas as Xanthomonas maltophilia (Hugh 1981) comb. nov. Int. J. Syst. Bacteriol. 33:409-413.

36. Willems, A., J. Busse, M. Goor, B. Pot, E. Falsen, E. Jantzen, B. Hoste, M. Gillis, K. Kersters, G. Auling, and J. De Ley. 1989. Hydrogenophaga, a new genus of hydrogen-oxidizing bacteria that includes Hydrogenophaga flava comb. nov. (formerly Pseudomonas flava), Hydrogenophaga palleronii (formerly Pseudomonas palleronii), Hydrogenophaga pseudoflava (formerly Pseudomonas pseudoflava and "Pseudomonas carboxydofiava"), and Hydrogenophaga taeniospiralis (formerly Pseudomonas taeniospiralis). Int. J. Syst. Bacteriol. 39:319333.

37. Willems, A., J. De Ley, M. Gillis, and K. Kersters. 1991. Comamonadaceae, a new family encompassing the acidovorans rRNA complex, including Variovorax paradoxus gen. nov., comb. nov., for Alcaligenes paradoxus (Davis 1969). Int. J. Syst. Bacteriol. 41:445-450.

38. Willems, A., E. Falsen, B. Pot, E. Jantzen, B. Hoste, P. Vandamme, M. Gillis, K. Kersters, and J. De Ley. 1990. Acidovorax, a new genus for Pseudomonas facilis, Pseudomonas delafieldii, EF group 13, EF group 16, and several clinical isolates, with the species Acidovorax facilis comb. nov,, Acidovorax delafieldii comb. nov., and Acidovorax temperans sp. nov. Int. J. Syst. Bacteriol. 40:384-398.

39. Willems, A., M. Gillis, K. Kersters, L. Van den Broecke, and J. De Ley. 1987. Transfer of Xanthomonas ampelina Panagopoulos 
1969 to a new genus, Xylophilus gen. nov., and Xylophilus ampelinus (Panagopoulos 1969) comb. nov. Int. J. Syst. Bacteriol. 37:422-430.

40. Willems, A., B. Pot, E. Falsen, P. Vandamme, M. Gillis, K. Kersters, and J. De Ley. 1991. Polyphasic taxonomic study of the emended genus Comamonas: relationship to Aquaspirillum aquaticum, E. Falsen group 10, and other clinical isolates. Int. J. Syst. Bacteriol. 41:427-444.

41. Woese, C. R., P. Blanz, and C. M. Hahn. 1984. What isn't a pseudomonad: the importance of nomenclature in bacterial classification. Syst. Appl. Microbiol. 5:179-195.

42. Woese, C. R., R. Gutell, R. Gupta, and H. F. Noller. 1983. Detailed analysis of the higher-order structure of $16 \mathrm{~S}$-like ribo- somal ribonucleic acids. Microbiol. Rev. 47:621-669.

43. Woese, C. R., W. G. Weisburg, B. J. Paster, C. M. Hahn, R. S. Tanner, N. R. Krieg, H.-P. Koops, H. Harms, and E. Stackebrandt. 1984 . The phylogeny of purple bacteria: the beta subdivision. Syst. Appl. Microbiol. 5:327-336.

44. Yabuuchi, E., I. Yano, H. Oyaizu, Y. Hashimoto, T. Ezaki, and H. Yamamoto. 1990. Proposals of Sphingomonas paucimobilis gen. nov. and comb. nov., Sphingomonas parapaucimobilis sp. nov., Sphingomonas yanoikuyae sp. nov., Sphingomonas adhaesiva sp. nov., Sphingomonas capsulata comb. nov., and two genospecies of the genus Sphingomonas. Microbiol. Immunol. 34:99-119. 